\title{
PENGARUH BEBERAPA INSEKTISIDA NABATI TERHADAP PERKEMBANGAN DAN MORTALITAS LARVA Crocidolomia pavonana Fabricius DI LABORATORIUM
}

(The Effect of Some Botanical Insecticides on Development and Mortality of Larvae Crocidolomia pavonana Fabricius in the Laboratory )

\author{
Mutia Aidia Nabilla ${ }^{1}$, Alfian Rusdy ${ }^{1}$, Hasnah $^{1 *}$ \\ ${ }^{1}$ Program Studi Proteksi Tanaman, Fakultas Pertanian, Universitas Syiah Kuala \\ *Corresponding author: hasnah@unsyiah.ac.id
}

\begin{abstract}
Abstrak. Crocidolomia pavonana Fabricius merupakan salah satu hama yang menyerang tanaman dari famili Brassicaceae.Tujuan dari penelitian ini adalah untuk mendapatkan jenis ekstrak yang efektif dalam mengendalikan hama C. pavonana. Tumbuhan yang bersifat sebagai insektisida nabati antara lain Anacardium occidentale L, Persea americana Mill, Blumea balsamifera L, Morinda citrifolia L dan Lantana camara L. Penelitian ini menggunakan metode Rancangan Acak Lengkap (RAL) nonfaktorial yang terdiri dari 5 perlakuan dan 4 ulangan. Hasil penelitian menunjukkan bahwa aplikasi beberapa insektisida nabati berpengaruh terhadap mortalitas dan penghambat makan larva $C$. pavonana. Pada pengamatan 7 HSA aplikasi ekstrak daun tembelekan dengan konsentrasi $10 \%$ mortalitas larva C. pavonana mencapai $67,50 \%$, selanjutnya diikuti ekstrak daun sembung $62,50 \%$. Pada pengamatan 7 HSA aplikasi ekstrak daun tembelekan dengan konsentrasi $10 \%$ persentase penghamabat makan mencapai $84,58 \%$, selanjutnya diikuti ekstrak daun sembung $79,73 \%$. Persentase pupa yang muncul pada ekstrak tembelekan yaitu 32,50\%. Dengan demikian, hasil penelitian menunjukkan bahwa aplikasi ekstrak daun tembelekan dan sembung lebih efektif dibandingkan aplikasi ekstrak daun jambu mede, alpukat dan mengkudu.
\end{abstract}

Kata kunci : Pengendalian, Crocidolomia pavonana, Ekstrak Nabati

Abstract. Crocidolomia pavonana Fabricius is one of the major pests which attack plants from family Brassicaceae. The aims of this research were to obtain the type of extract that is effective in controlling $C$. pavonana pests. Plants that act as botanical insecticides among others Anacardium occidentale L, Persea americana Mill, Blumea balsamifera L, Morinda citrifolia L and Lantana camara L. The experiment was conducted using a non-factorial Completely Randomized Design (CRD) with 5 treatments and 4 replications. The results showed that the application of several botanical insecticides had an effect on mortality and inhibited feeding of C. pavonana larvae. In the observation of 7 HSA application of tembelekan leaf extract with a concentration of $10 \%$, the mortality of C. pavonana larvae reached $67.50 \%$, followed by $62.50 \%$ sembung leaf extract. In the observation of $7 \mathrm{HSA}$, the application of tembelekan leaf extract with a concentration of $10 \%$, the percentage of food contaminants reached $84.58 \%$, followed by $79.73 \%$ of sembung. The percentage of pupae that appeared in the tembelekan extract was $32.50 \%$. Thus, the results showed that the application of tembelekan and sembung leaf extracts was more effective than the application of cashew, avocado and noni leaf extracts.

Keywords: Control, Crocidolomia pavonana, Botanical Extract

\section{PENDAHULUAN}

Ulat krop kubis (Crocidolomia pavonana F.) (sin. C. binotalis Zeller) ordo Lepidoptera famili Crambidae merupakan salah satu hama yang menyerang tanaman dari famili Brassicaceae antara lain kol, bunga kol, sawi, lobak dan radish (Pracaya, 1999). Serangga ini bersifat oligofag yaitu termasuk serangga pemakan beberapa jenis tanaman dari satu famili. Sejak 1973 telah diketahui bahwa C. pavonona merupakan hama yang berbahaya dan merugikan secara ekonomi di Indonesia, kehilangan hasil yang disebabkan oleh $C$. pavonona dapat mencapai 100\% pada musim kemarau (Sastrosiswojo, 1975).

Hama ini menyerang pada fase larva dengan memakan pucuk tanaman kubis, sehingga krop tanaman tidak terbentuk. Apabila krop tanaman telah habis di makan maka larva akan pindah ke bagian ujung daun, seterusnya turun ke daun yang lebih tua. Tanaman yang terserang akan rusak seluruhnya bila hama ini tidak dikendalikan secepatnya (Sastrosiswojo \& Setiawati, 1990). 
Umumnya petani mengendalikan hama ini memakai insektisida sintetik, tanpa memperdulikan dampak negatif terhadap lingkungan, misalnya pencemaran lingkungan sekitarnya seperti air, tanah serta dapat membunuh organisme non target (Mahmood et al.,2016). Berdasarkan Peraturan Pemerintah No 6 tahun 1995 ditetapkan bahwa perlindungan tanaman dilaksanakan dengan sistem pengendalian hama terpadu (PHT). Salah satu komponen pengendalian hama terpadu yaitu penggunaan insektisida nabati. Tanaman yang bersifat sebagai insektisida nabati antara lain jambu mede (Anacardium occidentale L.), alpukat (Persea americana Mill), sembung (Blumea balsamifera L.) mengkudu (Morinda citrifolia L.) dan tembelekan (Lantana camara L.).

Daun jambu mede bersifat insektisida nabati karena mengandung senyawa aktif antara lain, alkaloid, tanin, triterpenoid, saponin (Dzamic et al., 2009). Hasil penelitian Saenab et al. (2017) menyatakan bahwa, kulit cangkang jambu mede mengandung senyawa aktif utama yaitu asam anakardat. Hasil penelitian Dewi et al. (2018) menyatakan bahwa, aplikasi ekstrak kasar kulit biji jambu mede dengan konsentrasi $0,80 \%$ dapat mematikan larva $C$. pavonana 63\% setelah 3 HSA. Daun alpukat mengandung senyawa aktif berupa alkaloid, flavonoid, tanin, triterpenoid, dan steroid (Mufida et al.,2018).

Daun alpukat juga mengandung minyak atsiri antara lain IR- $\alpha$-pinene, camphene, sabinene, $\beta$-pinene, eucalyptol, 1,3,6-octatriene, 3,7-dimethyl-,(z)-, linalool, estragole, anethole, methyleugenol dan caryophyllene (Echegoyen et al., 2015). Hasil penelitian Adesina et al. (2016) bahwa, aplikasi ekstrak daun alpukat dengan pelarut etil asetat dengan konsentrasi $40 \mu \mathrm{l}$ dapat mematikan larva Anopheles gambiae 64,20\% setelah 1 HSA.

Daun tembelekan bersifat sebagai insektisida nabati, dan mengandung senyawa aktif steroid, tanin, saponin (Purwati et al., 2017). Tanin merupakan salah satu senyawa aktif yang dihasilkan oleh semua tumbuhan yang berperan sebagai penolak makan (antifeedant). Menurut Kasmara et al. (2017) bahwa, aplikasi ekstrak daun tembelekan dengan pelarut etanol konsentrasi $20 \mathrm{ml} / \mathrm{l}$ dapat mematikan larva Spodoptera litura 80\% setelah 2 HSA..

Daun sembung juga berpotensi sebagai pestisida nabati dengan senyawa aktif antara lain berupa alkaloid, flavonoid, saponin, glikosida dan terpenoid (Maslahat \& Yuliani, 2014) selain itu juga mengandung minyak atsiri antara lain, 1,8-Cineole, borneol, caryophyllene, 4terpeniol (Chu et al., 2012). Aplikasi ekstrak daun sembung dengan nilai LD50 dapat mematikan larva Plutella xylostella dengan berat badan $1,669 \mathrm{mg} / \mathrm{g}$ setelah 1 HSA (MoralloRejesus, 1986).

Daun Mengkudu bersifat larvisidal karena mengandung senyawa alkaloid, kumarin, flavonoid, tanin, saponin, steroid dan triterpenoid (Assi et al., 2017). Hasil penelitian Setiawati et al. (2018) menyatakan bahwa, aplikasi ekstrak daun mengkudu menggunakan pelarut etanol konsentrasi 5\% mortalitas larva C. binotalis mencapai 93,33\% setelah 48 jam setelah aplikasi. Berdasarkan permasalahan di atas maka perlu dilakukan penelitian untuk mengetahui tingkat keefektifan dari beberapa insektisida nabati dalam mengendalikan hama C. pavonana di Laboratorium.

Tujuan dari penelitian ini adalah untuk mendapatkan jenis insektisida nabati yang efektif dalam mengendalikan hama C. pavonana.

\section{Tempat dan Waktu Penelitian}

\section{METODE PENELITIAN}

Penelitian ini dilaksanakan di Laboratorium Hama Tumbuhan Jurusan Proteksi Tanaman dan Laboratorium Analisis Pangan Jurusan Teknologi Hasil Pertanian Fakultas 
Pertanian Universitas Syiah Kuala. Waktu pelaksanaan dimulai bulan Februari 2020 sampai dengan Maret 2020.

\section{Alat dan Bahan Penelitian}

Alat yang digunakan dalam penelitian ini adalah kotak serangga, timbangan analitik, kuas, pisau, stoples kaca, gunting, blender, saringan plastik, stoples plastik, pinset, batang pengaduk, cawan petri, lup, spet suntik, corong, spatula, gelas ukur, rotary evaporator, kamera, kulkas, oven dan alat tulis.

Bahan yang digunakan pada penelitian ini adalah daun jambu mede, alpukat, sembung, mengkudu dan tembelekan, methanol 70\%, karung beras, kain kasa, karet gelang, amplop surat warna kuning, kertas merang, kapas, kertas label, serbuk gergaji, sarung tangan, akuades, tween 20 , tanaman sawi, madu $10 \%$ dan larva $C$. pavonana.

\section{Rancangan Penelitian}

Pada penelitian ini menggunakan Rancangan Acak Lengkap (RAL) Non faktorial yang terdiri dari 5 perlakuan dan 4 ulangan sehingga diperoleh 20 unit percobaan.

\section{Prosedur Penelitian \\ Pembiakan Serangga Uji}

Larva $C$. pavonana di peroleh BPTP Aceh lalu dibawa ke Laboratorium Hama Tumbuhan kemudian dimasukkan ke dalam stoples plastik untuk pemeliharaan. Larva $C$. pavonanadiberikan pakan yaitu daun sawi segar yang diganti setiap hari. Larva instar V yang akan memasuki stadia pupa yang ditandai dengan berkurangnya aktivitas makan dan gerak, dipindahkan ke dalam stoples yang telah diisi dengan serbuk gergaji. Setelah memasuki stadia pupa maka dipindahkan ke dalam kotak serangga yang telah diisi dengan satu pot tanaman sawi segar. Setelah imago muncul selanjutnya diambil kapas yang telah dicelupkan ke dalam cairan madu dengan konsentrasi 10\% dan digantungkan dalam kotak serangga sebagai pakan bagi imago C. pavonana

Telur yang diletakkan oleh imago dipindahkan ke dalam stoples yang dialasi dengan kertas merang, dan dibiarkan sampai telur menetas, stoples tersebut ditutupi dengan kain kasa. Selanjutnya setelah telur menetas dimasukkan pakan daun sawi segar dan diganti setiap hari sampai larva memasuki instar II (serangga uji).

\section{Pembuatan Ekstrak Insektisida Nabati}

Tanaman yang akan dijadikan sebagai insektisida nabati antara lain daun sembung yang berasal dari Desa Teupin Batee A.Timur, daun tembelekan (Desa Kuta Lawah A.Timur) daun alpukat (Desa Pondok Baru Bener Meriah A.Tengah), daun Mengkudu (Desa Gampong Jalan dan Calok Geulima A.Timur) dan daun jambu mede (Desa Seunebok Timu A.Timur). Masing-masing daun tersebut dikering anginkan selama 2 minggu. Selanjutnya daun yang sudah dikering anginkan ditimbang sebanyak $500 \mathrm{~g}$ lalu digunting kecil dan diblender, sehingga diperoleh dalam bentuk serbuk kemudian dimasukkan ke dalam stoples kaca dan ditambahkan pelarut polar methanol sebanyak 2 liter, kemudian direndam selama 3 hari dan diaduk setiap 1 kali 24 jam. Selanjutnya simplasia tersebut diperas menggunakan kain kasa halus dan ditampung ke dalam stoples plastik. Setelah itu larutan tersebut dibawa ke Laboratorium Analisis Pangan untuk diuapkan dengan alat rotary evaporator pada suhu $60^{\circ} \mathrm{C}$ selama 3 jam sehingga didapat fraksi kasar yaitu daun jambu mede berbentuk sol sedangkan daun alpukat, sembung, mengkudu dan tembelekan berbentuk liquid. 


\section{Aplikasi Ekstrak pada Serangga Uji}

Masing-masing ekstrak dibuat adonannya sesuai dengan konsentrasi uji (Tabel 1). Setelah itu diambil daun sawi segar dan ditimbang sebanyak $50 \mathrm{~g}$ untuk setiap perlakuan, kemudian dicelupkan ke dalam masing-masing ekstrak (kontaminasi pakan) selama 5 detik lalu diangkat dan dikering anginkan selama 10 detik, kemudian dimasukkan ke dalam stoples yang telah berisi serbuk gergaji dan sudah dialasi dengan kertas merang. Selanjutnya dimasukkan larva uji $C$. pavonana instar II sebanyak 10 larva. Stoples ditutupi dengan kain kasa dan diikat dengan karet gelang lalu stoples tersebut diletakkan di rak percobaan, begitu juga untuk perlakuan lainnya dilakukan dengan metode yang sama.

\section{Peubah yang Diamati}

\section{Mortalitas Larva Crocidolomia pavonana}

Mortalitas larva diamati sejak satu hari sampai tujuh hari setelah aplikasi. Cara menghitung persentase mortalitas larva dengan menggunakan rumus Abbot (1925), dalam Prijono (1999) yaitu:

Keterangan :

$$
\mathrm{P} 0=\frac{r}{\mathrm{n}} \times 100 \%
$$

P0 : Mortalitas Larva

$\mathrm{r} \quad$ : Jumlah larva yang mati

n : Jumlah larva seluruhnya

\section{Persentase Penghambat Makan Larva $C$. pavonana}

Pengamatan dimulai satu hari setelah aplikasi sampai larva memasuki masa prapupa. Pengamatan dilakukan dengan cara daun sawi yang tersisa dalam stoples percobaan diangkat seluruhnya, lalu dimasukkan ke dalam masing-masing amplop, sesuai dengan perlakuan kemudian dimasukkan ke dalam oven pada suhu $40^{\circ} \mathrm{C}$ selama 2 hari. Pada pengamatan ini ada perlakuan kontrol dua stoples dengan memasukkan daun sawi segar sebanyak 50 gr dan serangga uji $C$. pavonana instar II sebanyak 10 larva dan pakan diganti setiap hari sampai memasuki masa prapupa. Perhitungan persentase penghambat makan menggunakan rumus (Prijono, 2003) sebagai berikut :

$$
\mathrm{PM}=\frac{B k-B p}{B k+B p} \times 100 \%
$$

Keterangan :

PM : Persentase penghambat makan

$\mathrm{Bk}$ : Bobot daun kontrol yang dimakan (g)

Bp : Bobot daun perlakuan yang dimakan $(\mathrm{g})$

\section{Persentase Pupa yang Muncul}

Persentase pupa yang muncul dihitung sejak larva memasuki fase prapupa sampai terbentuk pupa. Persentase pupa yang terbentuk dihitung dengan menggunakan rumus berikut:

$$
\text { Persentase pupa terbentuk }=\frac{\text { Jumlah pupa yang muncul }}{\text { Jumlah larva awal }} \times 100 \%
$$




\section{Mortalitas Larva C. pavonana}

\section{HASIL DAN PEMBAHASAN}

Hasil analisis ragam menunjukkan bahwa aplikasi beberapa insektisida nabati terhadap mortalitas larva $C$. pavonana berpengaruh tidak nyata pada pengamatan 1,2, 3 dan 4 HSA, sedangkan pada pengamatan 5, 6 dan 7 HSA berpengaruh nyata untuk lebih jelas berikut ini disajikan rata-rata mortalitas larva $C$. pavonana akibat aplikasi beberapa insektisida nabati pada Tabel 1 berikut:

Tabel 1. Rata-rata mortalitas larva C. pavonana akibat aplikasi beberapa insektisida nabati

\begin{tabular}{cccccccc}
\hline $\begin{array}{c}\text { Ekstrak } \\
\text { Daun } \\
(\mathbf{1 0 \%})\end{array}$ & $\mathbf{1}$ & $\mathbf{2}$ & $\mathbf{3}$ & $\mathbf{4}$ & $\mathbf{5}$ & $\mathbf{6}$ & $\mathbf{7}$ \\
\cline { 2 - 8 } & & & & & & \\
\hline Jambu & $24,16 \mathrm{a}$ & $27,86 \mathrm{a}$ & $27,86 \mathrm{a}$ & $29,36 \mathrm{a}$ & $30,87 \mathrm{a}$ & $36,00 \mathrm{a}$ & $37,66 \mathrm{ab}$ \\
mede & $(17,50)$ & $(22,50)$ & $(22,50)$ & $(25,00)$ & $(27,50)$ & $(35,00)$ & $(37,50)$ \\
\hline \multirow{2}{*}{ Alpukat } & $15,40 \mathrm{a}$ & $31,72 \mathrm{a}$ & $31,72 \mathrm{a}$ & $31,72 \mathrm{a}$ & $35,41 \mathrm{a}$ & $35,41 \mathrm{a}$ & $36,92 \mathrm{ab}$ \\
& $(12,50)$ & $(30,00)$ & $(30,00)$ & $(30,00)$ & $(35,00)$ & $(35,00)$ & $(37,50)$ \\
\hline \multirow{2}{*}{ Sembung } & $38,95 \mathrm{a}$ & $43,56 \mathrm{a}$ & $48,17 \mathrm{a}$ & $48,17 \mathrm{a}$ & $51,11 \mathrm{~b}$ & $51,11 \mathrm{~b}$ & $52,78 \mathrm{bc}$ \\
& $(40,00)$ & $(47,50)$ & $(55,00)$ & $(55,00)$ & $(60,00)$ & $(60,00)$ & $(62,50)$ \\
\hline \multirow{2}{*}{ Mengkudu } & $18,12 \mathrm{a}$ & $30,87 \mathrm{a}$ & $33,97 \mathrm{a}$ & $33,97 \mathrm{a}$ & $36,00 \mathrm{a}$ & $36,00 \mathrm{a}$ & $36,00 \mathrm{a}$ \\
& $(12,50)$ & $(27,50)$ & $(32,50)$ & $(32,50)$ & $(35,00)$ & $(35,00)$ & $(35,00)$ \\
\hline \multirow{2}{*}{ Tembelekan } & $32,53 \mathrm{a}$ & $39,17 \mathrm{a}$ & $48,17 \mathrm{a}$ & $48,17 \mathrm{a}$ & $54,00 \mathrm{~b}$ & $55,50 \mathrm{~b}$ & $55,50 \mathrm{c}$ \\
& $(30,00)$ & $(40,00)$ & $(55,00)$ & $(60,00)$ & $(65,00)$ & $(67,50)$ & $(67,50)$ \\
\hline BNT 0,05 & - & - & - & - & 15,54 & 14,86 & 15,99 \\
\hline
\end{tabular}

Keterangan: Angka-angka yang diikuti oleh huruf yang sama pada kolom yang sama tidakberbeda nyata berdasarkan uji Beda Nyata Terkecil (BNT) pada taraf 0,05. (data telah ditransformasi Arc sin $\sqrt{\mathrm{X}}),()=$ data sebelum ditransformasi $\operatorname{Arc} \sin \sqrt{\mathrm{X}}$

Tabel 1 di atas memperlihatkan bahwa, rata-rata mortalitas larva $C$. pavonana akibat aplikasi beberapa insektisida nabati berbeda tidak nyata pada pengamatan 1, 2, 3 dan 4 tetapi pada pengamatan 5, 6 dan 7 ada perlakuan yang berbeda nyata.

Pada pengamatan 5 HSA mortalitas larva $C$. pavonana pada ekstrak daun jambu mede berbeda tidak nyata dengan alpukat dan mengkudu tetapi berbeda nyata dengan ekstrak daun sembung dan tembelekan. Begitu juga pada pengamatan 6 HSA, namun pada pengamatan 7 HSA mortalitas larva $C$. pavonana pada ekstrak daun mengkudu berbeda tidak nyata dengan daun jambu mede dan alpukat, tetapi berbeda nyata dengan ekstrak daun sembung dan tembelekan. Secara umum sejak dari 1 sampai 7 HSA ada kecenderungan mortalitas tertinggi pada ekstrak daun tembelekan dan diikuti ekstrak daun sembung, sampai akhir pengamatan mortalitas larva $C$. pavonana pada ekstrak daun tembelekan $67,50 \%$, pada ekstrak sembung $62,50 \%$ dan mortalitas terendah pada ekstrak jambu mede dan alpukat 37,50\% serta ekstrak daun mengkudu $35 \%$.

Tinggi rendahnya mortalitas larva $C$. pavonana tergantung jenis ekstrak serta komposisi senyawa aktif yang dikandungnya. Pada penelitian ini mortalitas tertinggi pada ekstrak tembelekan hal ini berkaitan dengan senyawa aktif yang dikandungnya antara lain saponin bersifat racun perut dan minyak atsiri terutama sesquiterpene hydrocarbons dan $\beta$ caryophyllene yang bersifat sebagai fumigan. Senyawa kimia yang bersifat racun perut masuk ke dalam tubuh serangga melalui makanan sehingga mengganggu sistem pencernaannya. Senyawa aktif yang bersifat racun perut proses penyerapan sebagian besar terjadi di saluran pencernaan bagian tengah yang merupakan organ penyerap nutrisi serta tempat terjadinya 
proses sekresi enzim-enzim pencernaan yang akhirnya menimbulkan efek keracunan, hal ini terjadi karena saluran pencernaan bagian tengah tidak memiliki kutikula, sedangkan pada saluran pencernaan bagian depan dan akhir dilapisi oleh kutikula. Bila terjadi kerusakan pada saluran pencernaan bagian tengah maka aktivitas enzim akan terganggu dan proses pencernaan bekerja tidak optimum, oleh karena itu metabolisme tubuh serangga menjadi terganggu (Sastrodiharjo, 1979; Danusulistyo, 2011).

Minyak atsiri juga berperan sebagai insektisida karena secara umum ekstrak nabati yang mengandung minyak atsiri bekerja sebagai insektisida, dapat bersifat reppelent, attractant, antifeedant dan menghambat peletakan telur, karena minyak atsiri mempunyai rasa getir dan berbau menyengat sesuai dengan bau tumbuhan penghasilnya. Sesuai dengan pendapat Khater (2012) menyatakan bahwa, minyak atsiri dapat mengakibatkan toksisitas langsung pada serangga, penolakan makan, peletakan telur, repellen, dan atraktan. Sesuai dengan hasil penelitian Puspitalia et al. (2018) bahwa, aplikasi ekstrak daun tembelekan dengan konsentrasi $10 \%$ pada larva Spodoptera exigua mortalitasnya mencapai 78,26\%.

Mortalitas larva $C$. pavonana pada ekstrak daun sembung yaitu mencapai $40 \%$ pada 1 HSA dan $62,50 \%$ pada 7 HSA, sebagaimana diketahui bahwa ekstrak daun sembung mengandung senyawa aktif saponin, steroid, alkaloid, flavonoid dan tanin. Salah satu senyawa aktif dari ekstrak daun sembung yang bekerja sebagai racun kontak yaitu flavonoid. Flavonoid merupakan salah satu golongan senyawa fenol alam terbesar dalam tanaman dan merupakan senyawa kimia yang memiliki sifat insektisida, sesuai dengan pendapat Cania \& Setyanimgrum (2013) menyatakan bahwa, flavonoid bekerja sebagai inhibitor kuat pernapasan atau sebagai racun pernapasan. Hasil penelitian Lestari \& Rahmanto, (2020) menyatakan bahwa, aplikasi ekstrak daun sembung dengan konsentrasi $25 \mathrm{~g} / \mathrm{l}$ terhadap hama Achatina fulica menghasilkan mortalitas 50\% setelah 4 minggu aplikasi.

Rendahnya mortalitas larva $C$. pavonana pada ekstrak daun jambu mede, alpukat dan mengkudu, hal ini berkaitan dengan kandungan senyawa aktif pada bagian tanaman terutama pada bagian daun, senyawa aktif pada bagian daun umumnya lebih rendah dari pada biji dan buah. Sesuai dengan hasil penelitian Mahaputro (2011) bahwa aplikasi ekstrak kulit biji jambu mede konsentrasi 1\% menghasilkan mortalitas 20\% pada larva Spilarctia obliqua. Selanjutnya Ranjith et al. (2017)menyatakan bahwa, aplikasi ekstrak daun jambu mede dengan konsentrasi 7,5\% menghasilkan mortalitas 56,67\% terhadap imago Odontotermes obesus setelah1 HSA. Hasil penelitian Rahmawati et al. (2019) bahwa aplikasi ekstrak buah mengkudu dengan konsentrasi $0,01 \%$ dapat menghasilkan mortalitas $95 \%$ terhadap larva $C$. binotalis pada pengamatan 1 HSA, sedangkan aplikasi ekstrak daun mengkudu dengan konsentrasi $500 \mathrm{gr} /$ liter hanya menghasilkan mortalitas 10\% terhadap larva S. litura setelah 2 HSA (Sari et al., 2013). Hasil penelitian Leite et al. (2009) bahwa, aplikasi ekstrak biji alpukat dengan nilai LC50 yaitu $8,87 \mathrm{mg} / \mathrm{l}^{-1}$ terhadap Aedes aegypti, sedangkan hasil penelitian Putri et al, (2018) bahwa, aplikasi ekstrak daun alpukat dengan konsentrasi 5\% menghasilkan mortalitas $25 \%$ pada larva Culex quinquefasciatus setelah 3 HSA.

\section{Persentase Penghambat Makan Larva $C$. pavonana}

Hasil analisis ragam menunjukkan bahwa aplikasi beberapa insektisida nabati pada larva $C$. pavonana berpengaruh tidak nyata terhadap persentase penghambatan makan pada pengamatan 1, 2, 3, 4, 5 dan 7 HSA, sedangkan pada pengamatan 6 HSA berpengaruh sangat nyata untuk lebih jelas berikut disajikan rata-rata persentase penghambat makan larva $C$. pavonana akibat aplikasi beberapa insektisida nabati pada Tabel 2 berikut. 
Tabel 2. Rata-rata persentase penghambat makan larva $C$. pavonana akibat aplikasi beberapa insektisida nabati

\begin{tabular}{cccccccc}
\hline \multirow{2}{*}{$\begin{array}{c}\text { Ekstrak } \\
\text { Daun } \\
(\mathbf{1 0 \%})\end{array}$} & $\mathbf{1}$ & $\mathbf{2}$ & $\mathbf{3}$ & $\mathbf{4}$ & $\mathbf{5}$ & $\mathbf{6}$ & $\mathbf{7}$ \\
\cline { 2 - 8 } & & & & & & \\
\hline Jambu & $36,41 \mathrm{a}$ & $38,18 \mathrm{a}$ & $40,11 \mathrm{a}$ & $39,35 \mathrm{a}$ & $36,88 \mathrm{a}$ & $51,77 \mathrm{a}$ & $58,70 \mathrm{a}$ \\
mede & $(35,24)$ & $(38,23)$ & $(41,51)$ & $(40,22)$ & $(36,05)$ & $(61,49)$ & $(72,92)$ \\
\hline \multirow{2}{*}{ Alpukat } & $36,41 \mathrm{a}$ & $41,63 \mathrm{a}$ & $40,89 \mathrm{a}$ & $39,74 \mathrm{a}$ & $37,30 \mathrm{a}$ & $49,35 \mathrm{a}$ & $57,49 \mathrm{a}$ \\
& $(35,24)$ & $(44,16)$ & $(42,87)$ & $(40,91)$ & $(36,77)$ & $(57,52)$ & $(70,94)$ \\
\hline \multirow{2}{*}{ Sembung } & $38,77 \mathrm{a}$ & $42,70 \mathrm{a}$ & $44,86 \mathrm{a}$ & $44,03 \mathrm{a}$ & $41,85 \mathrm{a}$ & $58,95 \mathrm{~b}$ & $63,55 \mathrm{a}$ \\
& $(39,24)$ & $(46,01)$ & $(49,73)$ & $(48,28)$ & $(44,61)$ & $(73,13)$ & $(79,73)$ \\
\hline \multirow{2}{*}{ Mengkudu } & $34,53 \mathrm{a}$ & $37,81 \mathrm{a}$ & $40,84 \mathrm{a}$ & $39,70 \mathrm{a}$ & $34,88 \mathrm{a}$ & $50,30 \mathrm{a}$ & $61,62 \mathrm{a}$ \\
& $(32,17)$ & $(37,61)$ & $(42,78)$ & $(40,82)$ & $(32,71)$ & $(59,18)$ & $(77,30)$ \\
\hline \multirow{2}{*}{ Tembelekan } & $36,42 \mathrm{a}$ & $38,18 \mathrm{a}$ & $42,31 \mathrm{a}$ & 45,03 & $42,07 \mathrm{a}$ & $61,62 \mathrm{~b}$ & $67,42 \mathrm{a}$ \\
& $(35,29)$ & $(38,23)$ & $(45,32)$ & $(50,04)$ & $(44,92)$ & $(77,30)$ & $(84,58)$ \\
\hline BNT 0,05 & - & - & - & - & - & 6,68 & - \\
\hline
\end{tabular}

Keterangan: Angka-angka yang diikuti oleh huruf yang sama pada kolom yang sama tidakberbeda nyata berdasarkan uji Beda Nyata Terkecil (BNT) pada taraf 0,05. (data telah ditransformasi Arc sin $\sqrt{\mathrm{X}}),()=$ data sebelum ditransformasi $\operatorname{Arc} \sin \sqrt{\mathrm{X}}$

Berdasarkan Tabel 2 di atas dapat dilihat bahwa, rata-rata persentase penghambat makan larva C. pavonana akibat aplikasi beberapa insektisida nabati berbeda tidak nyata pada pengamatan 1, 2, 3, 4, 5 dan 7 tetapi pada pengamatan 6 HSA ada perlakuan yang berbeda nyata yaitu aplikasi ekstrak daun alpukat tidak berbeda nyata dengan jambu mede dan mengkudu tetapi berbeda nyata dengan ekstrak daun sembung dan tembelekan. Pada pengamatan 6 HSA bahwa persentase penghambat makan larva $C$. pavonana tertinggi pada aplikasi ekstrak daun tembelekan 77,30\% dan diikuti ekstrak daun sembung 73,13\% dan yang terendah pada aplikasi ekstrak daun alpukat 57,52\%.

Tinggi rendahnya persentase penghambat makan larva $C$. pavonana ini tergantung pada kualitas dan kuantitas pakan yang dikonsumsi larva dan jenis senyawa aktif yang dikandung oleh insektisida nabati tersebut, selain itu juga berkaitan dengan mortalitas larva $C$. pavonana sebelumnya. Pada akhir pengamatan persentase penghambat makan tertinggi terdapat pada aplikasi ekstrak daun tembelekan yaitu mencapai $84,58 \%$ diikuti oleh ekstrak daun sembung yaitu 79,73\% dan yang rendah pada ekstrak daun alpukat 70,94\%, jambu mede $72,92 \%$ dan mengkudu $77,30 \%$. Tingginya persentase penghambat makan pada ekstrak daun tembelekan berkaitan dengan komposisi senyawa aktif yang dikandungnya. Senyawa aktif dari daun tembelekan antara lain steroid, tanin, saponin, alkaloid dan flavonoid, umumnya senyawa saponin, tanin dan alkaloid yang bersifat sebagai antifeedant pada serangga. Selain tanin, senyawa alkaloid juga bersifat sebagai antifeedant karena rasa yang pahit sehingga menghambat aktivitas makan (Hopkins \& Hiiner, 2004; Yunita et al.,2009)

Hasil penelitian Javier et al. (2017) bahwa aplikasi ekstrak daun tembelekan dengan konsentrasi $8 \mathrm{mg} / \mathrm{mL}$ dapat menghambat aktivitas makan larva S. litura mencapai $61,37 \%$ setelah 1 HSA. Selanjutnya Puspitalia et al. (2018) menambahkan bahwa aplikasi ekstrak daun tembelekan konsentrasi $10 \%$ dapat menghambat aktivitas makan larva S. exigua sebesar 43\% setelah 2 HSA. Selanjutnya Persentase penghambat makan larva $C$. pavonana akibat aplikasi ekstrak daun sembung mencapai $73,13 \%$. Hal ini ada kaitannya dengan kandungan senyawa aktif ekstrak daun sembung antara lain saponin, steroid, alkaloid, flavonoid dan tanin. Reseptor kimia tersebut bekerja bersama reseptor kimia lainnya, dan menyebabkan gangguan persepsi rangsangan untuk makan (Mordue et al., 1998; Szentesi \& Bernays, 1984). 
Sesuai dengan hasil penelitian Dewi \& Dadang (2005) menyatakan bahwa aplikasi ekstrak daun sembung dengan konsentrasi 5\% dapat menghambat aktivitas makan larva S. litura sebanyak $8,5 \%$.

Rendahnya persentase penghambatan makan pada ekstrak daun jambu mede, alpukat dan mengkudu ada kaitannya dengan senyawa aktif yang dikandung oleh tumbuhan tersebut dimana dalam penelitian ini yang digunakan sebagai bahan uji adalah bagian daun yang kandungan senyawa aktifnya lebih rendah dibandingkan dengan buah. Hasil penelitian Dono \& Susanerwinur (2013) aplikasi ekstrak kulit biji jambu mede dengan konsentrasi 0,12\% menghasilkan $0,47 \%$ luas daun yang dikonsumsi larva $C$. pavonana setelah 2 HSA. Hasil penelitian Rahmawati et al. (2019) aplikasi ekstrak buah mengkudu dengan konsentrasi 20 ppm menghasilkan kerusakan krop paling rendah yaitu 60\% setelah 1 HSA. Ekstrak daun alpukat lebih bersifat racun kontak, sehingga persentase penghambatan makan ada kaitannya dengan jumlah larva $C$. pavonana yang masih hidup.

\section{Persentase Pupa yang Muncul}

Hasil analisis ragam menunjukkan bahwa aplikasi beberapa insektisida nabati berpengaruh nyata terhadap perentase pupa yang muncul. Rata-rata persentase pupa $C$. pavonana yang muncul setelah aplikasi beberapa insektisida nabati dapat dilihat pada gambar 1 berikut ini.

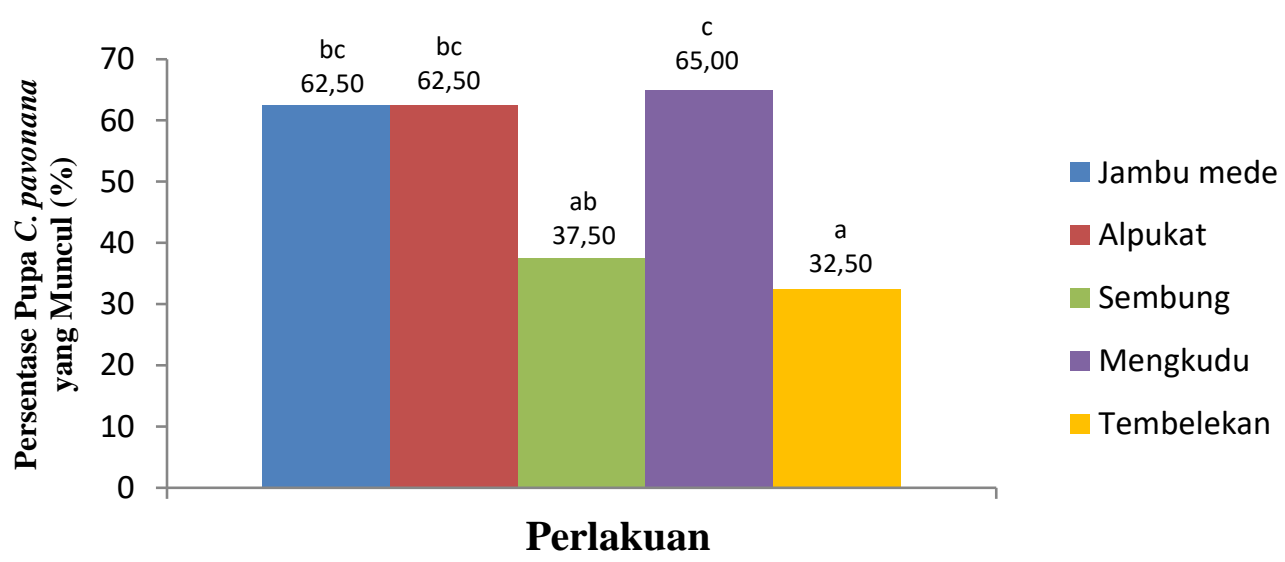

Gambar 1. Rata-rata persentase pupa yang muncul akibat aplikasi beberapa insektisida nabati pada 4 HSA

Gambar 1 menunjukkan bahwa persentase pupa $C$. pavonana yang muncul akibat aplikasi beberapa insektisida nabati ada perbedaan diantara perlakuan yang diujikan. Aplikasi ekstrak daun tembelekan berbeda tidak nyata dengan ekstrak daun sembung tetapi berbeda nyata dengan ekstrak daun jambu mede, alpukat dan mengkudu. Rata-rata persentase munculnya pupa tertinggi terdapat pada ekstrak daun mengkudu yaitu sebesar $65 \%$ dan diikuti oleh ekstrak jambu mede dan alpukat yaitu 62,50\%, sembung yaitu 37,50\% dan yang terendah terdapat pada perlakuan ekstrak tembelekan yaitu $32,50 \%$.

Tinggi rendahnya persentase pupaC. pavonana yang muncul pada setiap perlakuan berkaitan dengan data mortalitas larva $C$. pavonana sebelumnya, serta cara kerja dan kandungan senyawa aktif yang dikandung oleh masing-masing ekstrak. Pada penelitian ini persentase pupa $C$. pavonana yang muncul paling rendah terdapat pada ekstrak tembelekan, hal ini berkaitan dengan Senyawa aktif dari daun tembelekan antara lain saponin, steroid, alkaloid, tanin, terpenoid serta minyak atsiri.

Pada penelitian ini kegagalan pembentukan pupa serta imago erat kaitan dengan adanya gangguan hormonal diantaranya hormon ekdison.Sesuai pernyataan Muta'ali \& Purwani 
(2015), bahwa senyawa yang diduga mempengaruhi proses molting adalah saponin, karena saponin dapat mengikat sterol dalam saluran pencernaan dan berakibat menurunnya laju sterol dalam haemolimfa. Peran sterol bagi larva S. litura adalah sebagai prekursor bagi hormon ekdison, dengan adanya penurunan persediaan sterol, maka proses pergantian kulit akan terganggu. Gangguan pada hormon ekdison tersebut mempengaruhi metamorfosa serangga misalnya pembentukan kaki semu (proleg), pergantian instar dan pembentukan pupa (Cheng et al., 2014). Hasil penelitian Puspitalia et al. (2018) menyatakan bahwa aplikasi ekstrak daun tembelekan $2 \%$ pupa s. exigua yang muncul $60 \%$ tetapi pada aplikasi $8 \%$ pupa yang muncul hanya $16 \%$.

\section{KESIMPULAN DAN SARAN}

Ekstrak daun jambu mede, alpukat, sembung, mengkudu dan tembelekan berpotensi sebagai insektisida nabati, namun dari lima jenis ekstrak tersebut ekstrak tembelekan lebih tinggi daya racunnya dibandingkan dengan keempat ekstrak lainnya. Perlu dilakukan pengujian lanjutan dengan meningkatkan konsentrasi ekstrak daun jambu mede, alpukat, sembung, mengkudu dan tembelekan serta, pengujian dengan pelarut organik lainnya supaya dapat meningkatkan efektivitas dari kelima ekstrak dalam mengendalikan serangga hama $C$. pavonana.

\section{DAFTAR PUSTAKA}

Adesina, J. M., A. R. Jose, Y. Rajashekar \& K. D. Ileke. 2016. Persea americana (Mill.) Seed Extracts: Potential herbal larvacide control measure against Anopheles gambiae Giles, 1902 (Diptera: Culicidae) malaria vector. International J. of Mosquito Research. Vol. 3 (2): 14-17.

Assi, R. A., Y. Darwis, I. M. Abdulbaqi, A. A. Khan, L. Vuanghao \& M. H. Laghari. 2015. Morinda citrifolia (Noni): a comprehensive review on its industrial uses, pharmacological activities, and clinical trials. Arabian J. of Chemistry. Vol. 10: 691707.

Cania, E \& E. Setyanimgrum. 2013. Uji efektivitas larvasida ekstrak daun legundi (Vitex trifolia) terhadap larva Aedes aegypti. Medical J. of Lampung University. Vol. 2 (4): 52-60.

Cheng., Z. J., W. T. Min, L. L. Hua, W. Yang \& H. Lin. Wu. 2014. EcR-RNAi and azadirachtin treatments induced the abnormal proleg development in Spodoptera litura. J. of East China Normal University. 133-142.

Chu, S. S., S. S. Du \& Z. L. Liu. 2012. Fumigant compounds from the essential oil of Blumea balsamifera leaves against the maize weevil (Sitophilus zeamais). J. of Chemistry. 1-7.

Danusulistyo, M. 2011. Uji Larvasida Ekstrak Daun Lidah Buaya (Aloe vera L) terhadap Kematian Larva Nyamuk Anopheles aconitus Donitz. Skripsi. Fakultas Ilmu Kesehatan Masyarakat. Universitas Muhammadiyah. Surakarta (ID).

Dewi, M. S., D. Dono \& S. Hartati. 2018. Bioactivity of crude extract of cashew nut shell (Anacardium occidentale L.) against cabbage head caterpillar(Crocidolomia pavonana F.). J. Cropsaver. Vol. 1 (2): 85-92.

Dewi, R. S \& Dadang. 2005. Aktivitas biologi enam jenis ekstrak tumbuhan famili Asteraceae terhadap larva Spodoptera litura Fabricius (Lepidoptera: Noctuidae). J. Entomologi Indonesia. Vol. 2 (1): 51-60 
Dono, D \& Susanerwinur. 2013. Toksisitas dan anti oviposisi ekstrak metanol kulit biji Jambu mete (Anacardium occidentale L.) (Anacardiaceae) terhadap Crocidolomia pavonana F. (Lepidoptera : Pyralidae). Bionatura J. Ilmu-Ilmu Hayati dan Fisik. Vol. 15 (2): 79 82.

Dzamic, A., A. Gbolade, M. Ristic \& P. D. Marin. 2009. Essential oil composition of Anacardium occidentale from Nigeria. Chemistry of natural compound. Vol. 45 (3): 441-442.

Echegoyen, C. G., R. P. Pacheco, N. A. Hernandez, A. V. Lopez, L. L. Rivera \& A. R. Olivos. 2015. Chemical characterization and mosquito larvacidal activity of essential oil from leaves of Persea americana Mill (Lauraceae) against Culex quiqueasciatus (Say). Asian Pacific J. of Tropical Disease. Vol.5 (6): 463-467.

Hopkins, W. G \& N. P. A. Huner. 2004. Introduction to Plant Physiology. Third Edition. John Wiley and Sons, inc. Ontario.

Kasmara, H., Melanie, D. A. Nurfajri, W. Hermawan \& C. Panatarani. 2017. The toxicity evaluation of prepared Lantana camara nano extract against Spodoptera litura (Lepidoptera: Noctuidae). The 1st International Conference and Exhibition on Powder Technology Indonesia. 1-7.

Khater, H. F. 2012. Prospects of botanical biopesticides in insect pest management. $J$. Pharmacologis. Vol. 3 (12): 641-656.

Javier, A. M. V., V. R. Ocampo, F. A. Ceballo \& P. A. Javier. 2017. Insecticidal activity of selected essential oil extracts against commonds cutworm, Spodoptera litura Fabricius (Lepidoptera : Noctuidae). Philippine J. of Science. Vol. 146 (3): 247-256.

Leite, J. J. G., E. H. S. Brito, R. A. Cordeiro, R. S. N. Brilhante, J. J. C. Sidrim, L. M. Bertini, S. M. Morais \&M. F. G. Rocha. 2009. Chemical composition, toxicity and larvacidal and antifungal activities of Persea Americana (Avocado) seed extracts. J. Revista da Sociedade Brasileira de Medicina Tropical. Vol. 42 (2): 110-113.

Lestari, F \& B. Rahmanto. 2020. Toksisitas ekstrak bahan nabati dalam pengendalian hama Achantina fulica pada tanaman nyawai (Ficus variegata (Blume)). J. Wasian. Vol. 7 (1):39-50.

Mahaputro, G. K. 2011. Insecticidal activity of cashew nut shell liquid against two lepidopteran Pests. Indian J. of Entomology. Vol. 73 (2): 121-124.

Mahmood, I., S.R Imadi, K. Shazadi, Agul, \& KR Hakeem. 2016. Effect of pesticides on environment. plant, soil and microbes. Springer International Publishing Switzerland.

Maslahat, M \& N. Yuliani. 2014. Kandungan fitokimia, klorofil dan biomassa daun sembung (Blumea balsamifera) terhadap pencahayaan. J. Sains Natural. Vol. 4 (1): 11-25.

Morallo-Rejesus, B. 1986. Botanical insecticides against the diamondback moth. Department of entomology. Departement of Entomology. College of Agriculture University of the Philippines at Los Banos. College. Laguna, Philippines.

Mordue, A. J \& A. J. Nisbet. 2000. Azadirachtin from the neem tree Azadirachta indica:its action against insects. J. An. Soc. Entomol. Bras. Vol. 29 (4): 615-632.

Mufida., N. Rahman \& Supriadi. 2018. Efek ekstrak daun alpukat (Persea americana Mill.) dalam menurunkan kadar kolesterol darah pada mencit (Mus musculus). J. Akademika Kim. Vol. 7 (1):11-18.

Muta'ali, R \& K. I. Purwani. 2015. Pengaruh Ekstrak Daun Beluntas (Pluchea indica) terhadap Mortalitas dan Perkembangan Larva Spodoptera litura F. J. Sains dan Seni. Vol. 4 (2): 55-58.

Pracaya. 1999. Hama \& Penyakit Tanaman. Penebar Swadaya, Jakarta (ID). 
Prijono, D. 1999. Pengembangan dan Pemanfaatan Insektisida Alami. Pusat Kajian Pengendalian Hama Terpadu. Institut pertanian Bogor, Bogor (ID).

Prijono, D. 2003. Teknik Ekstraksi, Uji Hayati, dan Aplikasi Senyawa Bioaktif Tumbuhan. Panduan bagi Pelaksana PHT Perkebunan Rakyat. Departemen Hama dan Penyakit Tumbuhan fakultas Pertanian. Institut Pertanian Bogor, Bogor (ID).

Purwati, S., S.V.T. Lumowa, Samsurianto. 2017. Skrining fitokimia daun saliara (Lantana camara L) sebagai pestisida nabati penekanan hama dan insidensi penyakit pada tanaman hortikultura di Kalimantan Timur. Prosiding Seminar Nasional Kimia.

Puspitalia, N., Y. Liswarni \& H. Hamid. 2018. Uji konsentrasi ekstrak air daun Lantana Camara Linnaeus terhadap Mortalitas dan Perkembangan Spodoptera exigua Hubner (Lepidoptera: Noctuidae). Jurnal Proteksi Tanaman. Vol. 2 (1). hal. 28-36.

Putri, D. M., M. Ali \& Supriatno. 2018. Efektivitas larvasida ekstrak etanol daun alpukat terhadap mortalitas larva Aedes aegypty dan Culex quinquefasciatus. Jurnal Edubio Tropika.Vol. 6 (1). hal. 1-72.

Rahmawati, D., Djamilah, B. W. Simanihuruk. 2019. The effect of noni (Morinda citrifolia L.) fruit extract and time of application to control Crocidolomia binotalis Zell in cabbage plants. Akta Agrosia. Vol. 22 (1). p.13-21.

Ranjith, M., V. Deotale, D. R. Bajya, T. Manoharan \& M. Gajalakshmi. 2017. Evaluation of Termiticidal Activity and Phytochemical Analysis of Crotalaria burhia (Buch-Ham) and Anacardium occidentale (L.). Journal of Pharmacognosy and Phytochemistry. Vol. 6 (2). p. 172-176.

Saenab, A., K. G. Wiryaman, Y. Retnani \& E. Wina. 2017. Anacardic acid isolated from cashew nut shell (Anacardium occidentale) effects methane and other products in the rumen fermentation. Jurnal Media Peternakan. Vol. 40 (2). p. 94-100.

Sari, M., L. Lubis \& Y. Pangestiningsih. 2013. Uji efektivitas beberapa insektisida nabati untuk mengendalikan ulat grayak (Spodoptera litura F.) (Lepidoptera : Noctuidae) di laboratorium. Jurnal Online Agroteknologi. Vol. 1 (3). hal. 560-569.

Sastrodiharjo, M. 1979. Pengantar Entomologi Terapan. Penerbit ITB. Bandung.

Sastrosiswojo, S. 1975. Correlation between planting time of cabbage and population dynamics of Plutella maculipennis Curt and Crocidolomia binotalis Zell. Bull. Penel. Hort. Vol. 3. p.3-14.

Sastrosiswojo, S. \& W. Setiawati. 1990. Biology and control of Crocidolomia binotalis in Indonesia. Dalam : Talekar NS. Edit: Diamondback Moth and Other Cruciferae Pests. Proceeding of the Second International Workshop; 1990 Dec 10-14; Tainan. Taiwan (TW) AVRDC. p.81-87.

Setiawati, S., R. Hasibuan, Nuryasin \& Purnomo. 2018. Efikasi ekstrak daun mengkudu terhadap mortalitas larva Crocidolomia binotalis Zell. Jurnal Agrotek Tropika. Vol. 9 (2). hal. $99-104$.

Szentesi, A \& E. A. Bernays. 1984. A Study of behavioral habituation to a feeding deterrent in nymphs ofScistocerca gregaria. Journal Physiological Entomology. Vol. 9. p. 329340.

Yunita, E. A., N. H. Suprapti \& J. W. Hidayat. 2009. Pengaruh ekstrak daun teklan (Eupatorium riaprium) terhadap mortalitas dan perkembangan Larva Aedes aegypti.Jurnal Bioma. Vol. 1 (1). hal. 11-17. 